\title{
Causes of Time Overrun in Construction of Building Projects in Pakistan
}

\author{
Faheem Ahmed Soomro \\ Department of Civil Engineering, \\ Mehran University of Engineering and \\ Technology, Shaheed Zulfiqar Ali Bhutto \\ Campus, Khairpur Mirs, Pakistan \\ faheemahmed_soomro@yahoo.com
}

\section{Samiullah Sohu}

Department of Civil Engineering, Quaid-e-Awam University of Engineering, Science \& Technology, Nawabshah, Pakistan sohoosamiullah@gmail.com

\author{
Muhammed Jaffar Memon \\ Department of Civil Engineering, \\ Mehran University of Engineering and \\ Technology, Shaheed Zulfiqar Ali Bhutto \\ Campus, Khairpur Mirs, Pakistan \\ ja2far@gmail.com
}

\author{
Abdul Fattah Chandio \\ Department of Electronics Engineering, \\ Quaid-e-Awam University of \\ Engineering, Science \& Technology, \\ Nawabshah, Pakistan \\ fattahchandio@yahoo.com
}

\author{
Rizwanullah Soomro \\ Faculty of Civil Engineering, \\ Universiti Teknologi Malaysia \\ rizwantn16@gmail.com
}

\begin{abstract}
Time overrun in construction projects is a very serious issue in developed and developing countries. The main object of this research is to find the main causes of time overrun in the construction of building project and its possible mitigation measures. Quantitative approach was adopted in this research to achieve object and RIW (relative importance weight) approach was used for collecting data. Financial issues faced by the contractor, contractor's inexperience, weather impacts, late delivery of material, mistakes in design, shortage of skilled labor, incompetent subcontractor and mistakes in time estimation were identified as main causes of time overrun in construction projects and possible mitigation measures were also proposed from experts. This research will help in giving awareness to stakeholders to narrow down the factors of time overrun in construction projects in Pakistan.
\end{abstract}

Keywords-time overrun; causes; building projects; mitigation measures; Pakistan

\section{INTRODUCTION}

Time overrun is one of the most serious issues in construction industry globally [1]. "Construction time overrun is the change between a project's actual contract period at the time of tender and its final contract period on which construction project finished" [2]. Time overrun can result in many negative impacts on the construction project like budget overrun, low productivity, contract expiration, work acceleration resulting in bad quality, and disputes among construction stakeholders [3]. It is observed that many construction projects face the issue of time overrun worldwide both in developing and developed countries like USA or UK $[4,5]$. Authors in [6] stated that more than $40 \%$ of projects in construction industry experiences time overrun. Construction industry is not famous in terms of project completion within time. Ignorance of time overrun analysis resulted in many construction projects failing to complete on the given time frame [7]. According to [8] only $47 \%$ of projects were Corresponding author: S. Sohu completed within approved time frame, around $38 \%$ of construction projects were behind time frame and $15 \%$ of construction projects were completed ahead of time in Indonesia. Like other countries, time overrun is one of the most severe problems in the construction industry of Pakistan [9, 10]. Author in [11] reported that the majority of the Pakistan construction projects were $11 \%$ to $30 \%$ below their approved time fame. Only a few studies have been carried out to find factors of time overrun in the construction of building projects in Pakistan.

\section{PREVIOUS STUDIES}

Many researchers conducted studies on the causes of time overrun in different kinds of construction projects to find factors and causes of time overrun. Authors in [12] conducted survey on 130 randomly selected engineers. Identified causes of time overrun were delayed payments, material shortage, changes in selected material prices, poor site management, and problems in bank credit. Authors in [13] identified 83 common factors of time overrun and arranged these factors in 8 groups. By using relative importance index five causes of time overrun were identified which were poor supervision at site and site management, delay in making decisions, owner interference in the project, ground conditions, and necessary changes from the owner. Authors in [14] identified 16 causes of time overrun, the top 5 being: financial problems faced by the contractor, poor contract management, site supervision, lack of planning, and delay in material supply. Authors in [15] carried out a survey through questionnaire distribution to selected experts of construction industry in Nigeria. Identified causes of time overrun were inexperienced sub-contractors, shortage of labor, poor site management, shortage of selected materials and mistakes during works. Authors in [16] conducted survey about the causes of time overrun in infrastructure projects of Qatar. The results of the survey revealed that major causes of time overrun were design changes, inadequate planning and 
scheduling, changes in scope of project, inadequate estimation project time duration, and shortage of skilled labour. Authors in [17] identified the major causes of time overrun through quantitative approach in construction projects of Vietnam. The main causes of time overrun were poor monitoring, poor project management and financial problems faced by owner.

\section{RESEARCH METHODOLOGY}

This study was divided in two phases. In the first phase the objective was to find the main causes of time overrun and in the second phase was to find the mitigation measures of these identified causes. In the first phase, a literature review was carried out providing a total of 51 probable causes of time overrun. A questionnaire was developed, in which the aforementioned causes were imposed and respondents were asked to rank them. In the second phase, another questionnaire was distributed in which mitigation measures from literature review and unstructured interviews were incorporated.

\section{DATA COLLECTION AND ANALYSIS}

For the first phase, the developed questionnaire was distributed among 131 professional respondents (either consultants, clients or contractors) involved in handling the construction of building projects, 87 were received back and 84 were usable for data analysis (Table I). Table II indicates the respondents' qualification and Table III indicates their experience.

TABLE I. SURVEY DETAILS

\begin{tabular}{|c|c|}
\hline Parameter & Value \\
\hline Total distributed questionnaires & 131 \\
\hline Received back questionnaires & 87 \\
\hline Invalid questionnaires & 3 \\
\hline Valid questionnaires & 84 \\
\hline Percentage of valid questionnaires & 96 \\
\hline
\end{tabular}

TABLE II. QUALIFICATION OF RESPONDENTS

\begin{tabular}{|c|c|c|}
\hline Degree name & Frequency & Percentage \\
\hline Bachelor & 68 & 80.9 \\
\hline Master & 14 & 16.7 \\
\hline PhD & 2 & 2.40 \\
\hline Total & 84 & 100 \\
\hline
\end{tabular}

TABLE III. EXPERIENCE OF RESPONDENTS

\begin{tabular}{|c|c|c|}
\hline Experience & Frequency & Percentage \\
\hline 0-5 years & 8 & 9.52 \\
\hline 6-10 years & 24 & 28.58 \\
\hline 11-15 years & 21 & 25.00 \\
\hline 16-20 years & 18 & 21.43 \\
\hline 20 and above & 13 & 15.47 \\
\hline Total & 100 & 100 \\
\hline
\end{tabular}

For the first phase respondents were given questionnaires and were asked to rank each cause on a Likert scale. RIW approach was successfully used in previous studies giving accurate and good results [18]. The weight formula in $R I W$ was calculated as shown in (1):

$$
R I W=\frac{\sum a_{i} x_{i}}{\sum x_{i}}
$$

where $a_{i}$ shows a constant which represents the weight given to $i$, and $x_{i}$ is a variable denoting the frequency of the answer for $i$. The values are established from $x_{1}$ having the least importance and $a_{1}$ being 1 , to $x_{5}$ for most significant and $a_{5}$ equal to 5 . The results are shown in Table IV.

TABLE IV. CAUSES OF TIME OVERRUN

\begin{tabular}{|c|c|c|}
\hline Rank & Identified Causes & RIW Value \\
\hline 1 & Financial issues faced by contractor & 0.834 \\
\hline 2 & Inexperienced contractor & 0.831 \\
\hline 3 & Weather impact & 0.812 \\
\hline 4 & Delay in supply of materials & 0.783 \\
\hline 5 & Mistakes in design & 0.769 \\
\hline 6 & Shortage of skilled labour & 0.761 \\
\hline 7 & Incompetent subcontractor & 0.688 \\
\hline 8 & Errors in time estimation & 0.511 \\
\hline
\end{tabular}

\section{A. Financial Issues Faced by Contractor}

Financial issues faced by the contractor were found as the most major cause of time overrun. Contractors play important role from execution to completion of a project. Construction activities are suspended and stopped by the contractors due to financial issues [19]. Continuous funding to contractors can help to complete project on approved time.

\section{B. Inexperienced Contractor}

Inexperienced and incompetent contractor can cause time overrun. Selection of contractor on favoritism causes time overrun in construction projects [20].

\section{Weather Impact}

Most buildings constructed in tropical regions face chances of heavy rains, floods and earthquakes which affect construction activities causing delays on building projects. Weather impact causes time overrun from approved time in construction projects [21].

\section{Delay in Supply of Materials at Site}

Construction site of building is often located at remote and sometimes in tropical areas, so it is difficult to have a continuous supply of materials on time. Delay in material supply creates gaps in construction activities at site which causes time overrun in construction projects [22].

\section{E. Mistakes in Design}

Before project tendering, easy and accurate design should be prepared. Mistakes in design delay the project construction activities which can lead the project to time overrun [23].

\section{F. Shortage of Skilled Labor}

Shortage of skilled labor is one of the main causes of time overrun in the construction industry. Pakistan is a developing country and many workers are not skilled enough. Another cause of shortage of skilled labour is that many construction projects are running simultaneously [24].

\section{G. Incomplete Subcontractor}

Contractor appoints subcontractors for the completion of different activities of the project but appointment of incompetent subcontractor, can cause construction activities to run very slow compared to the given schedule. Incompetent, 
with no experience contractors and subcontractors do many mistakes during construction [25].

\section{H. Errors in Time Estimation}

Errors in making estimation of time duration because of lack of experienced engineers or planners leads to improper estimation of completion period of project. Estimation of project length is based on resources and their output [26]

\section{Mitigation MEASURES}

The second phase of this study was to identify mitigation measures of the identified causes. A questionnaire was developed having mitigation measures identified from literature review and interviews from experts. The respondents were asked to highlight their relative importance on a Likert scale. The collected data were analyzed by using RII (relative importance index) and the results are shown in Table V.

TABLE V. MITIGATION MEASURES OF CRITICAL FACTORS

\begin{tabular}{|c|c|}
\hline Mitigation Measure & Value \\
\hline Adequate funds should be allocated for each project. & 3.0 \\
\hline Highly experienced contractors should be appointed. & 2.97 \\
\hline Proper arrangements should be done in flood and rainy seasons & 2.94 \\
\hline Suitable resources should be used for supply of materials. & 2.91 \\
\hline Well reputed consultants should be hired. & 2.90 \\
\hline Skilled labor should be with facilities. & 2.89 \\
\hline Favorite subcontractor should not be appointed. & 2.88 \\
\hline Proper filed investigation should be made. & 2.86 \\
\hline
\end{tabular}

\section{CONCLUSION}

The purpose of this study was to find the major causes of time overrun in the construction projects in Pakistan and possible mitigation measures. After statistical analysis, the major causes of time overrun were: financial issues faced by the contractor, inexperienced contractor, weather impact, delay in supply of materials at site, mistakes in design, shortage of skilled labour, incompetent subcontractor, and errors in time estimation. Possible mitigation measures to control these causes were recognized and are depicted in Table $\mathrm{V}$. The outcomes of this study will help stakeholders to control causes of time overrun.

\section{REFERENCES}

[1] R. F. Aziz, A. A. Abdel-Hakam, "Exploring delay causes of road construction projects in Egypt", Alexandria Engineering Journal, Vol. 2, No. 5, pp. 16-23, 2016

[2] M. Y. Honrao, D. B. Desai, "Study of delay in execution of infrastructure projects-highway construction", International Journal of Scientific and Research Publications, Vol. 5, No. 6, pp. 1-8, 2015

[3] G. Kikwasi, "Causes and effects of delays and disruptions in construction projects in Tanzania", Australasian Journal of Construction Economics and Building-Conference Series, Vol. 1, No. 2, pp. 52-59, 2013

[4] M. Tafazzoli, Dynamic Risk Analysis of Construction Delays Using Fuzzy-Failure Mode Effects Analysis, PhD Thesis, University of Nevada, USA, 2017

[5] Y. A. Olawale, M. Sun, "Cost and time control of construction projects: inhibiting factors and mitigating measures in practice", Construction Management and Economics, Vol. 28, No. 5, pp. 509-526, 2010
[6] H. M. P. Moura, J. M. C. Teixeira, B. Pires, "Dealing with cost and time in the portuguese construction industry", CIB World Building Congress, Cape Town, South Africa, May 14-17, 2007

[7] O. Duran, Current Risk Management Applications in Turkish Construction Industry, MSc Thesis, University of Gaziantep, Turkey, 2006

[8] C. T. Amoatey, Y. A. Ameyaw, E. Adaku, S. Famiyeh, "Analysing delay causes and effects in Ghanaian state housing construction projects", International Journal of Managing Projects in Business, Vol. 8, No. 1, pp. 198-214, 2015

[9] S. Haq, Y. Rashid, M. S. Aslam, "Effects of delay in construction projects of Punjub-Pakistan: An emperical study", Journal of Basic and Applied Scientific Research, Vol. 4, No. 4, pp. 98-104, 2014

[10] S. Sohu, N. A. Memon, S. A. Abbasi, M. A. Pahore, K. Ullah, "Causes of Delay in Highway Projects in Pakistan", 8th International Civil Engineering Congress, Karachi, Pakistan, December 23-24, 2016

[11] Z. K. Bangash, "Analyzing the Causes of Delays in Construction Projects for Peshawar: Contractor Perception”, Journal of Emerging Trends in Applied Engineering, Vol. 1, No. 3, pp. 12-18, 2016

[12] F. D. K. Fugar, A. B. Agyakwah-Baah, "Delays in building construction projects in Ghana", Australasian Journal of Construction Economics and Building, Vol. 10, No. 1-2, pp. 103-116, 2010

[13] D. W. M. Chan, M. M. Kumaraswamy, "Reasons for delay in civil engineering projects - The case of Hong Kong", Transactions, Vol. 2, No. 3, pp. 1-8, 1996

[14] N. R. Mansfield, O. Ugwu, T. Doran, "Causes of delay and cost overruns in Nigerian, Construction project", International Journal of Project Management, Vol. 12, No. 4, pp. 254-260, 1994

[15] D. O. Ogeno, Factors Influencing Completion of Construction Projects in Kenya: A case of Government Buildings Construction Projects in Nairobi County, Kenya, MSc Thesis, University of Nairobi, Kenya, 2016

[16] H. Emam, P. Farrell, M. Abdelaal,"Causes of delay on infrastructure projects in Qatar”, 31st Annual ARCOM Conference, Lincoln, UK, September 7-9, 2015

[17] L. Le-Hoai, Y. D. Lee, J. Y. Lee, "Delay and cost overruns in Vietnam large construction projects: A comparison with other selected countries", KSCE Journal of Civil Engineering, Vol. 12, No. 6, pp. 367-377, 2008

[18] G. Ballard, L. Koskela, G. Howell, T. Zabelle,"Production System Design in Construction", 9th Annual Conference of International Group for Lean Construction, Singapore, August 6-8, 2001

[19] Y. Frimpong, J. Oluwoye, "Significant Factors Causing Delay and Cost Overruns in Construction of Groundwater Projects in Ghana", Journal of Construction Research, Vol. 4, No. 2, pp. 175-187 2003

[20] W. Alaghbari, M. R. A. Kadir, A. Salim, Ernawati, "The significant factors causing delay of building construction projects in Malaysia". Engineering, Construction and Architectural Management, Vol. 14, No. 2, pp. 192-206, 2007

[21] A. H. Al-Momani, "Construction delay: a quantitative analysis", International Journal of Project Management, Vol. 18, No. 1, pp. 51-59, 2000

[22] A. S. Faridi, S. M. El-Sayegh, "Significant factors causing delay in the UAE construction industry", Construction Management and Economics, Vol. 24, No. 11, pp. 1167-1176, 2006

[23] R. F. Aziz, "Ranking of delay factors in construction projects after Egyptian revolution", Alexandria Engineering Journal, Vol. 52, No. 3, pp. 387-406, 2013

[24] M. Sambasivan, Y. W. Soon, "Causes and effects of delays in Malaysian construction industry", International Journal of Project Management, Vol. 25, No. 5, pp. 517-526, 2007

[25] A. Senouci, A. Ismail, N. Eldin, "Time Delay and Cost Overrun in Qatari Public Construction Projects", Procedia Engineering, Vol. 164, pp. 368-375, 2016

[26] G. Sweis, R. Sweis, A. A. Hammad, A. Shboul, "Delays in construction projects: The case of Jordan", International Journal of Project Management, Vol. 26, No. 6, pp. 665-674, 2008 